DOI: 10.20472/IAC.2017.034.017

ZVI M. GANOR

West Galilee Academic College School of Management, Israel

\title{
THE EXPERIENCE-PROFIT CHAIN CUSTOMER EXPERIENCE ROLE IN MARKETING STRATEGY
}

\begin{abstract}
:
In the last 15 years 'customer experience' has raised the attention of researchers in the fields of 'marketing strategy', 'consumer behavior' and 'retail management'. The issues of 'experience', the 'game' and the 'search for pleasure and excitement' are not new .

Theoretical Framework - "the experience- profit chain"

The cause-to-effect link: Customer evaluation of lived experience ), hedonistic and utilitarian), creates a highest 'customer value judgement' that breeds a remarquable 'Customer Loyalty' , and 'customer life-time value' \& equity that breeds profit. This model was widely discussed by Pine \& Gilmore- (The Experience Economy 1999). Pine \& Gillmore argue about improving Customer Value to raise loyalty, competitiveness $\&$ profitability , businesses must orchestrate memorable events for their customers. In order to contributes to a competitive added-value edge.

This value chain was previously introduced by the pioneering study of Heskett, Sasser \& Schlesinger (1997) and later approved by James L. Heskett, Earl Sasser' Joe Wheeler research (The Service Profit Chain 2008)

We also referred to the Holbrook M. model of customer experience framework :"Hedonistic \& Utilitarian values mix (Customer Value,Framework for Analysis \& Research).

Previous researches like Reichheld, (The Loyalty Effect 2001), provide us with an excellent study guidance to link loyalty and profit.

Research objectives

Our research was conducted on a sampling of 1650 young users aged 18 to 24 years in Israel during 2014-16.

Our study was performed on three levels of field research:

Level A ( quantitative )

Examined the relationship between the shopping experience mix which is critical to create the highest satisfaction level among young customers, and their future purchase intention $\&$ habits.

Level B (quantitative)

Examines the relationship between customers satisfaction level, their Brand loyalty intentions, and 'Customer life time value' .

Level C ( qualitative )

Was conducted on 35 stores located in 4 malls where the quantitative research was performed.

Outcome \& Recommendations

Combining the five factors of customer experience in the marketing strategy (security, enjoyment, value, convenience, and evaluation)

of the business can significantly improve:

- The attractiveness of the purchase store.

- The extension of customers' in store time spending

The customer loyalty \& 'life-time-value' breed the increase of income and profit phase, This 1 year,
\end{abstract}


Level $C^{\prime}$ research is conducted on 35 stores. It started in January 2015. Our primary exploratory qualitative research confirm our assumptions of clear experience profit linkage.

\section{Keywords:}

CUSTOMER EXPERIENCE; CUSTOMER SATISFACTION; CUSTOMER LOYALTY; CORPORATE PROFIT; EXPERIENCE-PROFIT CHAIN 